\title{
The MarshaL’s Batons IN THE EgyPTIAN MUSEUMS
}

\author{
By \\ Dr. Islam Asem Abdelkareim
}

Lecturer of Modern and contemporary history

High Institute of Tourism of Abukir

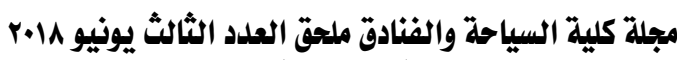

الخاص بملتقى شباب الباحثين الدولي التولي الأول

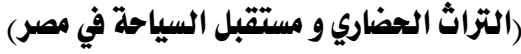




\title{
LETTERS OF THE KING DJED KARE-ISESI
}

\author{
Dr Islam Asem Abdelkareim'.
}

Four of Marshal's batons are shown in four Egyptian museums, the first in Abdeen palace museum in Cairo, the second in the Royal jewelry museum in Alexandria, the third in the military museum in Saladin Citadel in Cairo, and the fourth in Sadat museum in Alexandria. This paper will deal with the origin of the marshal's baton and it existence in Egypt, through describing the known batons in Egypt and prove its importance and the events related to each one of it, and story that could tell about that's to make a full documentation of each piece and to give the tour guides sufficient information, that help them to get rid of the descriptive way that some of them used to describe this objects

Keywords: Marshal's Baton- King Farouk- King Fuad I- Sadat- Egyptian Army, museum.

\section{Introduction:}

The marshal's baton is a stick carried as a mark of rank, ${ }^{r}$ but according to the definitions of word "Marshal" in the dictionaries, it is explained as it was originally refer to a high official in the household of medieval king, prince or noble origin having charge of cavalry ${ }^{r}$, so the history of the word "marshal" assure that it have derived from Germanic compound "markhaskalkaz", which consists of two syllabus "markhas" which means "horse" and "skalaz" which means "servant" to mean "keeper of the horse" then became the official in charge of the cavalry, then in the fourteenth centaury the term start to go out of Germany and start to lose its original mean to be a high official in the household of a king or duke. 'Later it refers to the most senior army mark in certain armies, or a military official of the highest rank ${ }^{\top}$.

After identifying the meaning of the marshal's baton, it is important to trace it is origin throughout the history.in the ancient civilizations like the Egyptian, there were various batons to be hold by the pharaoh, like the mace of king Narmer that considered by scholars the origin of the modern marshal's baton.

In ancient Greece, the baton was a sign of the messenger's immunity. ${ }^{\wedge}$ another opinion considered that the origin of the marshal's baton is a cipher device, dates back to 9 .. B.C., was called "Scytale",(plate no. ') 
which was a wooden cylinder of specific dimensions around which they wrapped spirally a piece of parchment or leather; they then wrote the message on the parchment, unwound it, and sent it to its destination by a safe courier, who handed it over to the commander for whom it was intended and who, having been provided with an identically dimensioned cylinder, would wind the strip of leather or parchment around his cylinder and thus bring together properly the letters representing the message.

In the Roman Empire was the baton was a consul's symbol of office, and a mark of honor and position;" then during the Fatimids period(979. $1 / \mathrm{V})$, the king during the important ceremonies and feasts had to have in his had a baton was called "king's bar قضيب الملك", which is a 1.0 handspan" gilded baton inlaid with gems and precious stones. 'r In the Mamluks period ( $1 Y 0 .-101 \mathrm{~V}$ ) there was a baton take the same shape of the marshal's baton to be in the hand of the sultan and its name was "Jūmūq جمق" which was a stick with rounded gilded end till it became with a baton bearer who was called "Jūmūqdār جمقدار ".'

the first use of the baton by a military officers was by the French during the reign of king Louis $1 \varepsilon^{\text {th }}\left(17 \leqslant 0_{-} \mid V_{10}\right)$ and it was with a gold ends with light blue velvet covering the shaft, decorated with gold fleurs-de-lys, then England took the custom from the French, that the first marshal's baton was presented to the duke of Wellington following his victory over the French on rI June $1 \mathrm{~N} / \mathrm{r}$, when he captured the baton of the French marshal Jourdan and sent it to the prince regent who became the king George IV afterwards, then the last presented to the former in return the first marshal baton in England, which has the same design till now, red velvet baton topped with golden allegory of St. George slaying the dragon, with the shaft decorated with crowned lions. ' ${ }^{\prime}$ (Plate no. ${ }^{r}$ )

In the light of the previously mentioned, the marshal as a military rank, and the custom of presenting this rank with a baton, has a French origin that has been circulated to England, then to the majority of the countries where the British conquered, or their military leaders studied in their military collages, but the marshal baton as a symbol of authority has an ancient origin took various shapes but the same function.

Hence, it is important to study the marshal's batons that shown in the Egyptian museums, to clarify the reason behind having it in Egypt, its significance, what symbol represent and it development. Hereafter, four batons will be described and discussed from historical point of view. 


\section{1- The marshal's baton of King Fuad I.}

In the hall of decorations and orders in Abdeen palace museum in Cairo, the marshal's baton of king Fuad I ( $191 V_{-} \mid 9 r_{7}$ ) is shown (Plate no. $\left.{ }^{r}\right)$, with the height of or $\mathrm{cm}$. and diameter $\varepsilon . r \mathrm{~cm}$., ${ }^{10}$ the baton takes a cylindrical shape covered with red velvet adorned with $r \tau$ golden crescents with pentagrams, ${ }^{17}$ ordered in four vertical lines, two lines with seven and the other two with six.

The top of the baton adorned with a golden crown with a crescent and pentagram finial, the crown comes out of golden cone-shape ornament which trimmed with a band of leaves. Between the two bands there is two oxidized silver king's name, in Diwani Arabic calligraphy, between two branches of laurel. The base of the baton has the same golden cone-shape ornament like that one on the top of the baton, but in upside down position to serve as a base. (Plate no. $\varepsilon$ )

Without the name of the king's Fuad I on that baton, it would have been hard to believe that this baton belongs to him, especially that there is no one picture representing him with a marshal's baton, even if those few pictures of him in military uniform, that's might be accepted because of king Fuad I desire in not wearing the military uniforms, only in the certain occasions that obligatory has to put on, the reason of this, it can be found in his own words, he said "I noticed that my way of thinking in the things when I wear it (military uniform), it is totally different when I put on my normal clothes"'v , so this baton belongs to king Fuad I but he might be never used it.

On one hand, there is no accurate date or a dedication phrase on the baton which makes the dating of the baton need more study. So through the marks on the rim of the cone-shape ornaments in the top and the base of the baton, between the two riveting bolts, could be the key to know its date and the occasion of its dedication.

The mark of lion face emphasis that this baton was made in London, as this the London assay office mark, '^ with the marks refer to $1 \wedge$ carat gold of England, ${ }^{19}$ in addition to the letter $\mathbf{B}$ that refer to the year $19 r r,{ }^{r}$ besides, the crescents with the pentagram on the shaft of the baton, which was the symbol of Egypt in the sultanate time and then it was changes to be a crescent with three pentagrams, that's leads to make the date of the dedication is between $r{ }^{\text {th }}$ Feb. $19 r r$ when Britain declared the unilateral declaration of Egyptian independence ${ }^{r}$ till the time of changing 
the flag by the law no. $\leqslant V$ in $19 r r$, ${ }^{r}$ after the proclamation of the constitution on $19^{\text {th }}$ April $19 r$ r.

On the other hand, the red velvet that covers that shaft of the baton could lead to the color of the Egyptian flag before it turned to green color during the kingdom era, that might be an acceptable reason of choosing the red color but there is another reason behind this color, that this baton was made in London, so by a simple comparison with the standard shape of the English marshal's batons, the resemblance is clear, it both have the same design and color and shape, only two differences the first one is instead of the crown on the top there is a representation of St. George slaying the dragon and the second is instead of the crescent with the pentagram there is a crowned lion, which means that the red color here not referring to the sultanate flag or whatsoever but it's part of the official shape of the English marshal's baton.

On the whole, we can conclude that this marshal baton was presented to king Fuad I from England, in the period from $r \wedge^{\text {th }}$ Feb. $19 r r$ to $19^{\text {th }}$ April $19 \mathrm{rr}$, in the occasion of the independence of Egypt, even if it was nominal, to congratulate him in taking the full authority on Egypt, especially on the Egyptian army.

\section{$r$ - The ebony marshal's baton of King Farouk I.}

In the Royal Jewelry museum in Alexandria, the ebony field's marshal baton of King Farouk I ( $19 r_{-}$) $90 \mathrm{r}$ ) is shown (Plate no. ${ }^{\circ}$ ), with 04 $\mathrm{cm}$. height and $0 \mathrm{~cm}$. diameter, ${ }^{r}$ with ${ }^{\circ} r \cdot$ grams golden chain of $\left.r\right)$ carats of England, the baton weights $9 \leq 0 . r$ gr. ${ }^{r}$ The cylindrical ebony baton takes the shape of an ancient Egyptian column that has a golden capital of a blooming lotus and its pistil adorned with engraving of king Farouk I name, in Diwani calligraphy, between two branches one to the left is of oak and the other to the right is of laurel, and down to the two branches is engraved

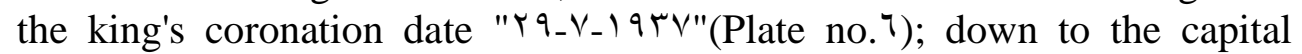
goes two golden rings around the baton, between the rings, there is a very well executed golden hawk-winged sun disk with two cobras, which was an ubiquitous motif in the ancient Egyptian time, representing the god Horus of Behdet ${ }^{\text {ro }}$ symbol of protection.

The base of the baton takes the same capital of a blooming lotus but its pistil adorned with a high relieve of a golden royal Egyptian crown with a crescent and pentagram star finial and down to this capital, the golden chain wraps around the baton. The shaft adorned with the royal Egyptian 


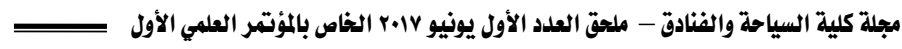

symbol the crescent with ${ }^{r}$ pentagrams ${ }^{r v}$ repeated eighteenth time, ordered in four vertical lines, two lines with five and the other two with four.

Through this description, it can be deduce that the baton made in England and presented to the king in the occasion of his coronation, without the Council of Regency, when he attained his majority eighteen lunar years according to the Law of Succession ${ }^{r \wedge}$ in $r q^{\text {th }}$ July $19 r v$, and that could give an explanation to why there are eighteen crescent on the shaft of the baton?, so it is quite clear that was intentionally done to symbolize the eighteen lunar months.

To present the king with the marshal's baton on his coronation day, was important sign as it represent his full authority of the army and that according to the constitution, that's according to article $\leqslant r$ that tells "The King creates and grants civil and military ranks, orders and other titles of honor.." ${ }^{\Upsilon q}$, and article $\leqslant 7$ that tells "The King is the Commander-in-chief of land and navy forces and shall appoint and dismiss officers, declare war, make reconciliations, and conclude treaties..." ${ }^{r}$, both articles gave the king the supreme authority in dealing with the army, so it was logic that King Farouk I received a marshal's baton, so this baton represent the authority of the king on the Egyptian army.

The baton appeared in the hand of king Farouk I in one of the most important event in his political life that was during the historical visit of king of Saudi Arabia Abdul-Aziz Al-Saud ( $9 r_{-} r_{-} 904$ ) to Egypt in January 19 97 , (plates no. $\vee, \wedge, 9$ and $) \cdot$ ) when he came to repay the visit of king Farouk to Saudi Arabia in 19 190 , and to fasten the relationship between the two kingdoms, and to negotiate the establishment of the Arab league.'

In the fifth day of the visit on Monday 1 s $^{\text {th }}$ January $19 \leq 7$ king Farouk I invited his honorably guest to the biggest military parade in the history of the Egyptian Army ${ }^{r r}$ then, in the desert of Almazah east of Cairo, with participation of $r, \cdots$ soldiers, because of the greatness of the event it was covered by more than 1. photographers, that was the biggest number of them to cover an event. "So there are four pictures of this occasion represent king Faruok I in the military uniform with the baton in the left hand.

The circumstances of these pictures represent how king Farouk I with the military uniform, holding in his left hand the Ebony marshal's baton, that reflect his authority that was given by the Egyptian constitution, and to send a message that he a legal powerful ruler with full ability to leads the Arab countries. 


\section{r- The Ivory marshal's baton of King Farouk I.}

In the order and decoration hall in the military museum at Saladin citadel in Cairo, the Ivory marshal's baton of King Farouk I is shown. (Plate no. 11$)$ With $0 \cdot \mathrm{cm}$. high and $\varepsilon \mathrm{cm}$. diameters and a $0 . r \cdot$ gr. of $r l$ carat gold chain, with London assay office mark, the baton weights $9 r \mathrm{r} . \wedge$ gr.

The baton takes the shape of Palmiform column, ${ }^{\text {ro }}$ with an incised capital of eight palm fronds lashed to the top of the baton, coming out from the Capital a royal Egyptian crown with a crescent and pentagram star finial, of $1 \wedge$ carat gold. The base of the baton has a high relieve of papyrus stem sheaths of the base of the Papyriform column.

Down to the capital, there is a golden ring covered with white and green enamel. Followed by a wider golden ring, which has a high relieves in

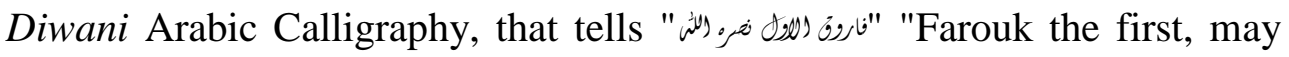
god help him to be victorious", on a blue enamel background. Followed by another golden ring, then the insignia of the royal artillery between two olive branches, the badge, executed in red enamel gold, which consists of the royal crown on the top of a torch then two crossed tank canons on a triangle of seven points; then the artillery slogan, written in Arabic, that tells "المدفعية الملكية فِّ كل مكان" "the royal artillery in everywhere".

The shaft of the baton adorned with ir golden pentagram stars, each star has a name of one of Mohamed Ali Dynasty victorious battles engraved in Arabic with the year of the battle, which are "Acre

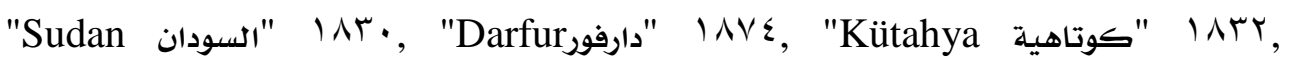

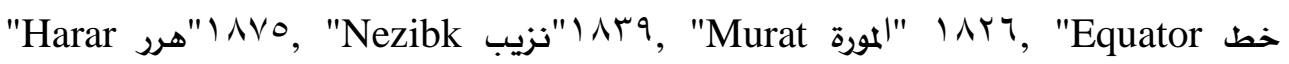

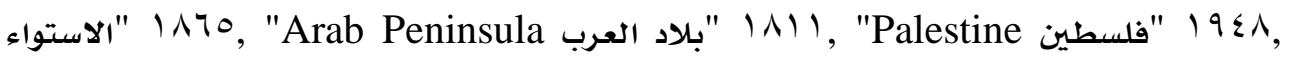

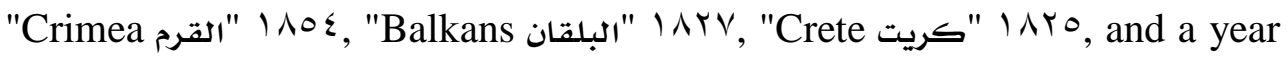
engraved on the base is 1 Tr r $19 \leq 0$.

Consequently, the baton was presented to the king Farouk I from the Egyptian royal artillery as a symbol of loyalty in 19 190 , but the battles names on the baton has a star with Palestine with the year $19 \leqslant \wedge$ which means that this baton was dedicated firstly in 19 190 , then a new star was added after Palestine war $19 \leqslant \wedge$.

Furthermore, King Farouk appeared with this baton in a two pictures $^{r v}$, in the first picture (plate no. $1 r$ ) king Farouk I in his military uniform seated in the middle, with the ivory marshal's baton in his left hand. Seating to his right Mahmoud Fahmy ElNokrashi pasha who was the prime 
minister of Egypt two times in the reign of the king Farouk the first period was from $r \varepsilon^{\text {th }}$ Feb. $19 \leqslant 0$ to $10^{\text {th }}$ Feb. $19 \leqslant 7$, the second period was from $9^{\text {th }}$ Dec. $19 \leq 7$ till his assassination in $r \lambda^{\text {th }}$ Dec. $19 \leq \wedge$, then Ahmed Atia pasha, is seated to the right of the Prime minister, who was the national defense minister in the second cabinet of ElNokrashi, but only from $9^{\text {th }}$ Dec. $19 \leq 7$ till $19^{\text {th }}$ Nov. $19 \leqslant \vee{ }^{\mu \wedge}$ when king Farouk insist to change him with Mohamed Haider Pasha.

Then to the left of the king there are the grand Chamberlin Omar Fathy pasha and the president of the Royal court then to his left the minister of finance Ibrahim AbdelHady Pasha who became also president of the royal court in $11^{\text {th }}$ Feb. $19 \leqslant \mathrm{~V}$, " and many others of the Egyptian army.

According to the time span of each minister, it can be deduce that this picture was taken in the period starts in $11^{\text {th }} \mathrm{Feb}$. 19 $9 \mathrm{~V}$ when Ibrahim AbdelHady Pasha became president of the royal court to be accompanying the king in a military occasion, till before $19^{\text {th }}$ Nov. 19 $1 \mathrm{v}$, when Ahmed Atia Pasha was resigned. The second picture (plate no. 1 r) shows king Farouk I receiving a gift from the army officers while he is holding in his left hand the ivory marshal's baton but here appears Mohamed Haider Pasha the minister of national Defense from $19^{\text {th }}$ Nov, $19 \leqslant V$ to $1 \mathrm{r}^{\text {th }}$ Jan. 190..$^{\text {s }}$

\section{\& - The ebony marshal's baton of Sadat.}

Mrs. Gihan Sadat dedicated to bibliotheca Alexandrina a lot the personal belongings of Egypt former president Sadat, to establish a museum inside the Library, One of the remarkable pieces shown in the museum is the ebony marshal's baton of Sadat (plate no. I $\varepsilon$ ), with the height of $0 . \mathrm{cm}$. and $r \mathrm{~cm}$. diameter. ${ }^{\xi}$

The Ebony baton takes the shape of an ancient Egyptian temple column with a composite capital with blooming papyrus flower, its pistil

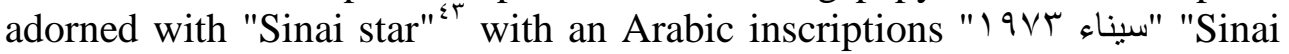
$19 \vee \% "$. The petals of that flower are blooming and closed lotus flowers alternatively, each petals colored with green, red and blue. All of that comes out of five meander lines represent, the word $m w$ in ancient Egyptian language that means water, here resembling Suez Canal, then there are a donation phrase in white Arabic inscription on an indigo background, that tells:

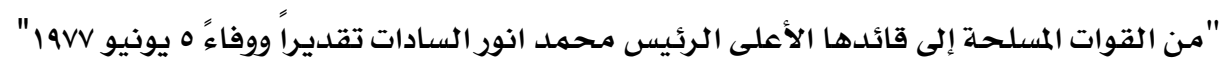

"From the armed Forces to its supreme commander the president

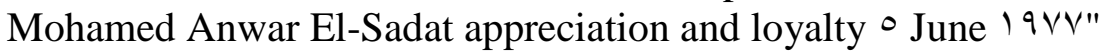


Then there is the emblem of the supreme commander which composed of two crossed swords between two laurel branches forming a circle which close on the top with the hawk of the Egyptian flag then, the hawk breast adorned with the Egyptian flag colors. Then the rest of the baton adorned with a branch of laurel goes in cylindrical way around the baton, till a decorative bronze base which the baton end with.

This baton was dedicated to President Sadat after giving a speech in his meeting with the second Army, on $0^{\text {th }}$ May l9v , in the occasion of the reopening of the Suez Canal. The baton was presented by the vice primeminister and the minister of the armed forces, General Mohamed AbdelGhany EL-Gamasy, to express the appreciation, trustfulness, loyalty and thankfulness of Egyptian Armed Forces to the supreme commander president Sadat ${ }^{\text {s }}$.

In that occasion they named the baton "the leadership baton" not "Marshal's baton", what lead us to understand that this baton not referring here to the Marshal as military rank but it represent the highest rank in the army. And what confirm this opinion that the General EL-Gamasy was promoted to Marshal Rank but without a Marshal's baton or whatsoever.

The baton was symbol of leadership and in the opinion of president Sadat himself was a necessity to complete the military uniform, (plate no. 10) and that may be clear from what was told by Jehan Sadat "To stress the pride and importance he had always felt serving as an officer in the Egyptian Army, he would finish out his appearance by carrying a field marshal's baton under his arm, an affectation which I did not like." People will think you are showing off, and you are not a show-off," I would protest. But, insisting that his stick represented "the true style of military life," he always carried it anyway. Except for that last October $7^{\text {th }}$, did he forget it? Or did he not take it out of deference to me?":0

By other words, Sadat wanted to send a massage by his military appearance holding his baton that confirm his supremacy over the army that cause the victory in 19vr, so he emphasis his power and authority by this baton, and this massage was not so clear for many who considered his military uniform with the marshal's baton is representing his "Flashness" and "love of pomp and status" $"$.

According to mentioned words of Jehan Sadat, related between this baton and the life of the late president, made others imagining that in this baton was his luck and protection phylactery which cause his death by forgetting taken it with him when he was assassinated. 


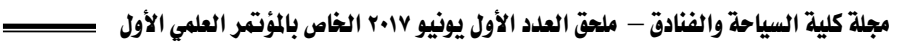

\section{Results and Conclusion}

Throughout this study on the four marshal's batons that shown in the Egyptian museums, it can conclude that the batons were made of various materials like gold, ivory and Ebony, and were decorated with various floral ornaments like papyrus flower, lotus flower, laurel leaves, oak leaves and palm fronds. Also, animal motifs were used in decoration like the cobra and the hawk wings, besides, the geometrical design like stars, pentagrams, crescents and meander lines, with the scripting design as Diwani calligraphy.

Besides, it is proved how important is the marshal's baton to the Egyptian rulers, and represent an important events in the modern history of Egypt, the marshal's baton might be presented from other countries to the ruler of Egypt, like what happened with king Fuad I, or from the army to the ruler like king Farouk and President Sadat; and for all of them wasn't presented for obtaining the marshal military rank, but to represent the supreme authority of the ruler of the army according to the Egyptian constitution, and represent also the army loyalty to its supreme commander.

the batons of king Fuad I and his son farouk I are designed in England, that represent who was those kings related to Britain in General to receive a gift from it, or to make the batons there, as we found that the gold in the three batons with British hallmark signs.

Finally, it is obvious the importance of the marshal's baton from the historical side, and it's proved how rich with symbols and decorations that could be used in the explanation of the tour guides, so it is recommended to take more care in the way of demonstrating it in the museums, and to put the related historical photos beside it, to complete the experience of the museum visitors by a historical events and knowing how their owners looks like. 


\section{Plates}

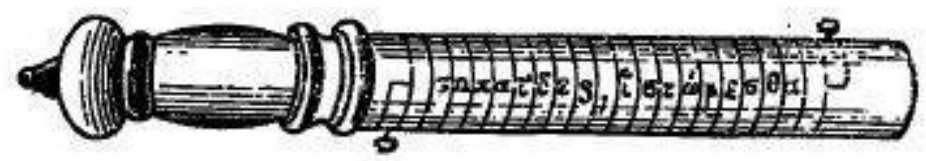

After: William Frederick Friedman, Six Lectures Concerning Cryptography and Cryptanalysis, Aegean Park Press, California, $199 \cdot$, p. $r \cdot$

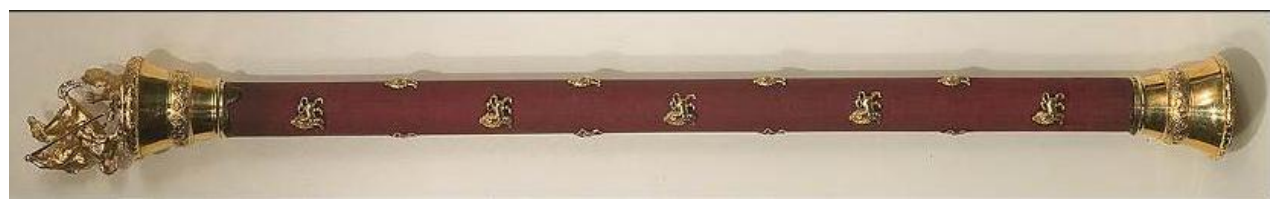

Plate no. ${ }^{\text {: }}$ : The marshal's baton of King Edward VIII- after: Corinna Pike and Christopher Mccreery, Canadian Symbols of authority, Dundurn, Toronto, $r .11$, p. 09

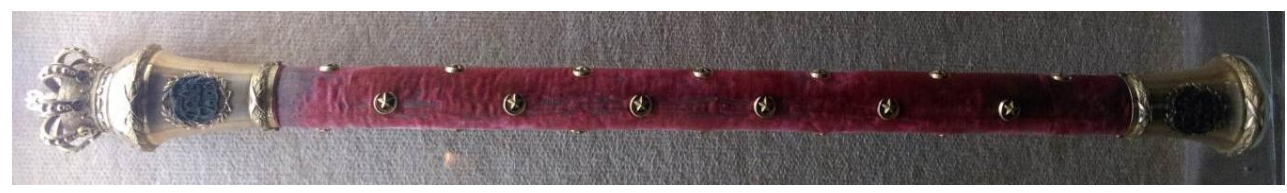

Plate no.r: the marshal's baton of King Fuad I (by the researcher)
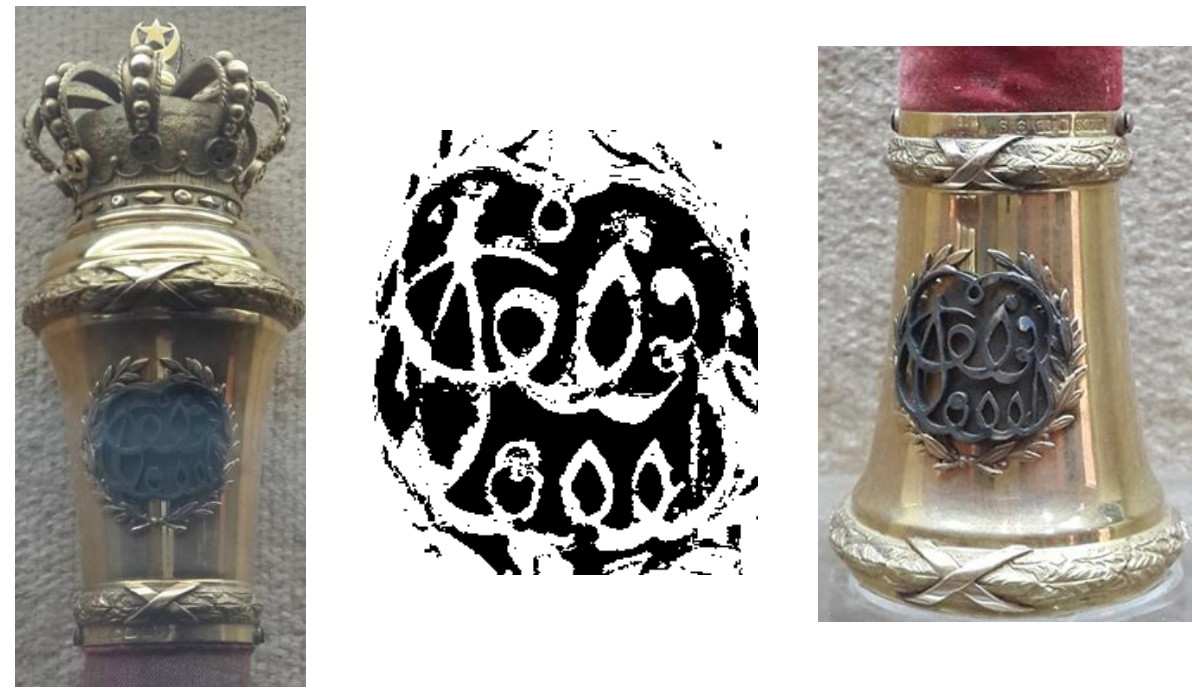

Plate no. $\varepsilon$ : the top and the base of the marshal's baton of King Fuad I, in between the name of king Fuad I in Diwani Calligraphy (by the researcher)

\section{\&.}




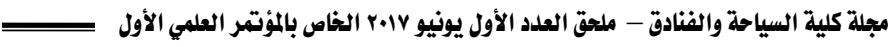

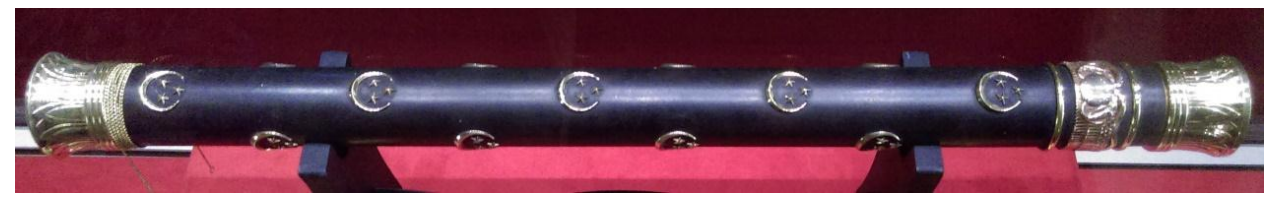

Plate no. ${ }^{\circ}$ : the ebony marshal's baton of King Farouk I (by the researcher)
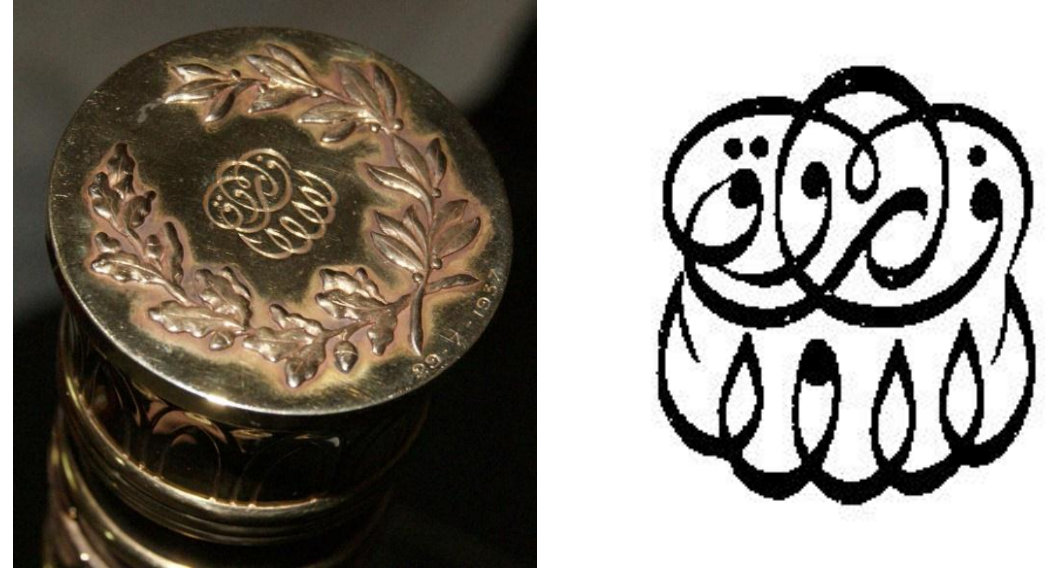

Plate no. ${ }^{7}$ : the base of the ebony marshal's baton of King Farouk I with the name of the king and the date (by the researcher)

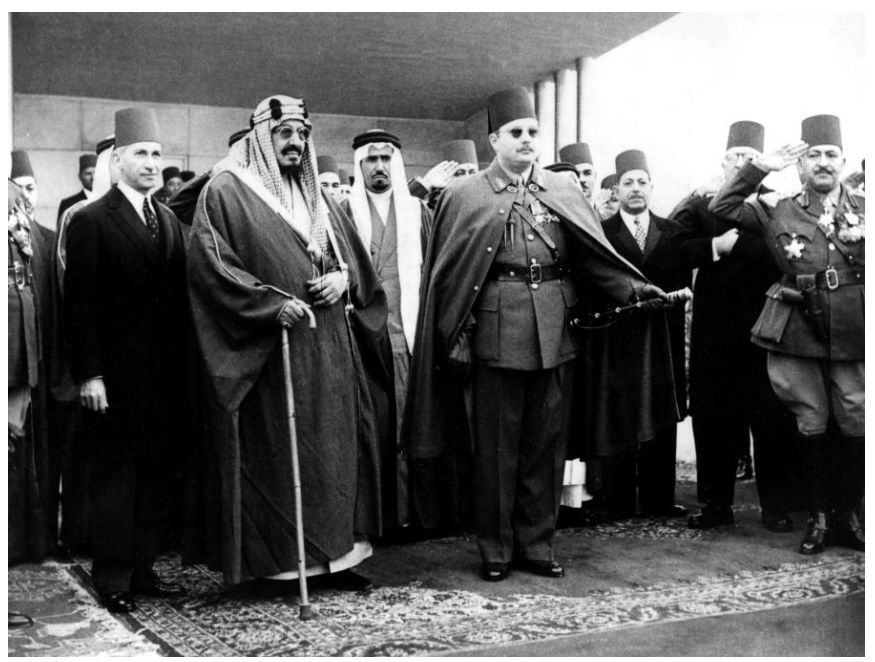

Plate no. ${ }^{\vee}$ : king Farouk I with the marshal's baton in his left hand, with King Abdul-Aziz Al-Saud, the Prime Minister El-Nokrashi pasha to the left of the king, and to the right of King Abdul-Aziz Ahmed Hassanein pasha, the chamberlain to King Farouk- in Almazah before the military parade

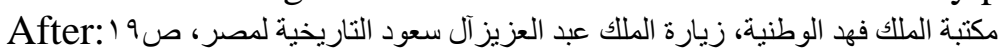




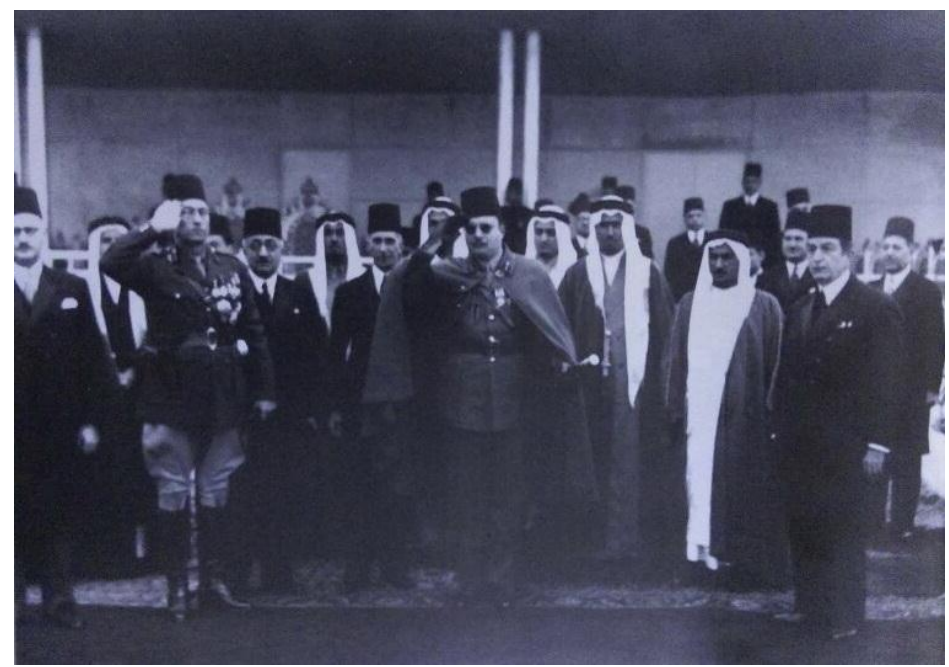

Plate no.^: king Farouk I with the marshal's baton in his left hand with the sons of King Abdul-Aziz Al-Saud and to his left hands appears Ahmed Atia pasha, the minister of the national Defense.in Almazah before the arrival of Saudi Arabia king to start the military parade

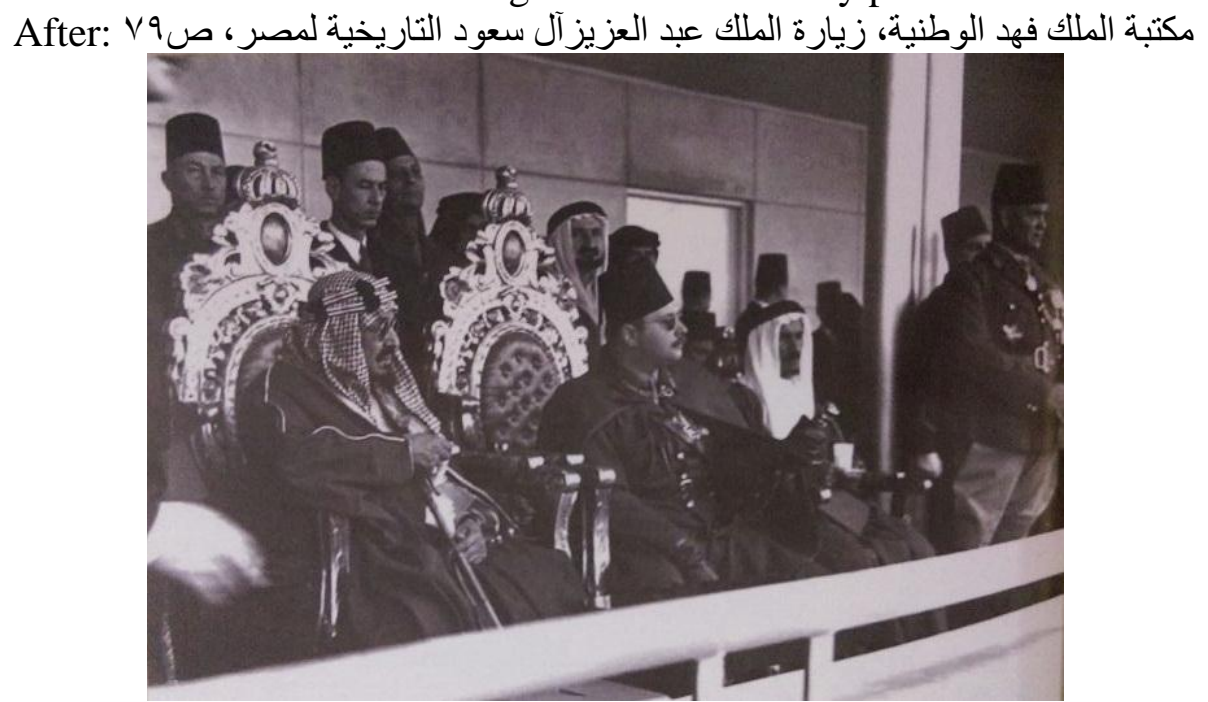

Plate no. ${ }^{9}$ : king Farouk I with the marshal's baton in his left hand with King Abdul-Aziz Al-Saud and to his left hands, both seated watching the military parade in Almazah, and behind between the two thrones appears AbdulRahaman Azam pasha who became the first secretary-general of the Arab league.

After: مكتبة الملك فهد الوطنية، زيارة الملك عبد العزيز آل سعود التاريخية لمصر، صس؟ 


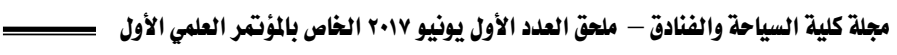

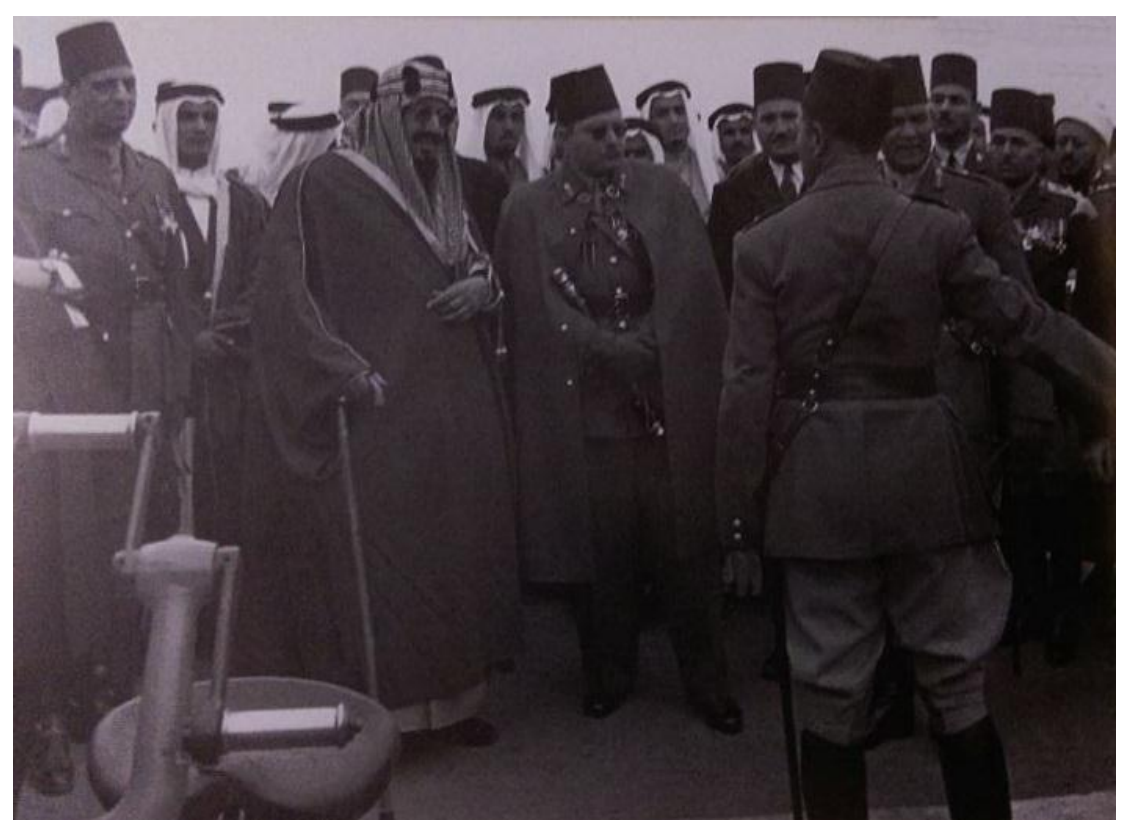

Plate no. ' $\because$ : king Farouk I with the marshal's baton in his hand with King Abdul-Aziz Al-Saud, both seated hearing the explanation about the heavy artillery.

After: مكتبة الملك فهد الوطنية، زيارة الملك عبد العزيز آل سعود التاريخية لمصر، صسالمب

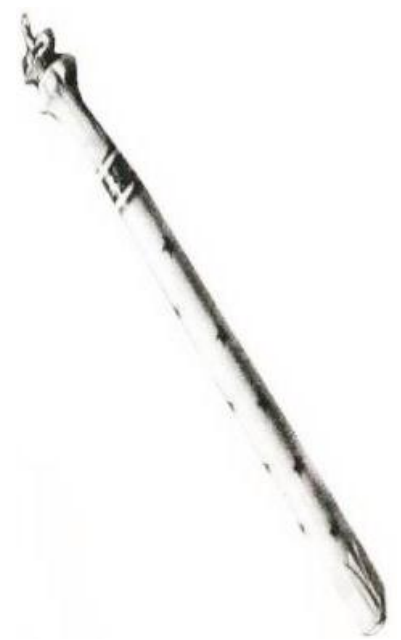

Plate no. 1 ' : the ivory marshal's baton of king Farouk I After: رأفت عبدالرازق ابو العينين، الازياء الثرفية والعسكرية وزينتها في عصر الاسرة

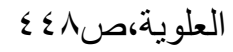




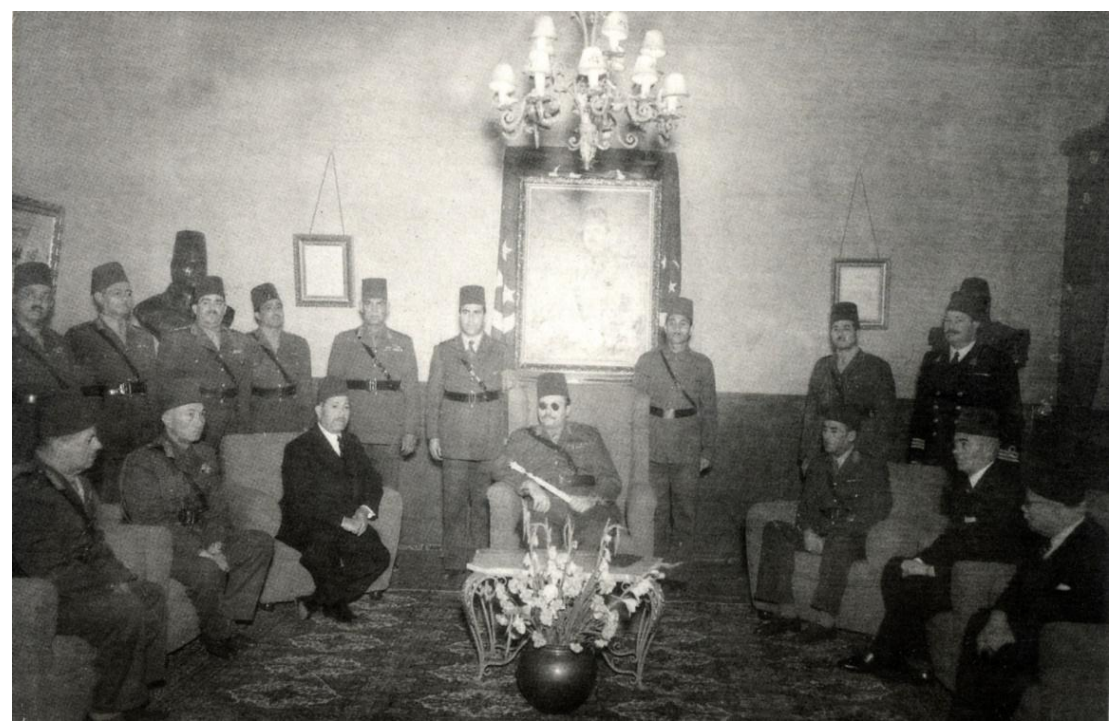

Plate no. 1 : king Farouk I with the ivory marshal's baton in his left hand, to the right of the king El-Nokrashi pasha then Ahmed Atia pasha, the left of the king Omar Fathy pasha, then Ibrahim Abdul-Hady pasha After: Bibliotheca Alexandrian Archive

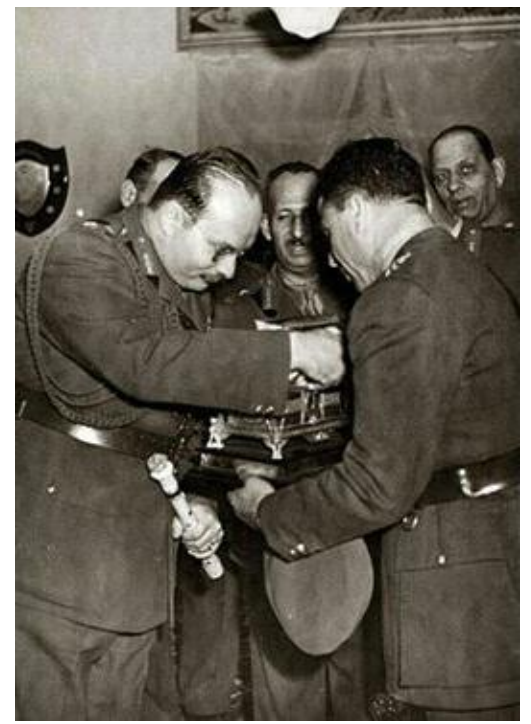

Plate no. 1 : the ivory marshal's baton of king Farouk I, while he receiving a gift from the army officers.

After: Bibliotheca Alexandrian Archive 


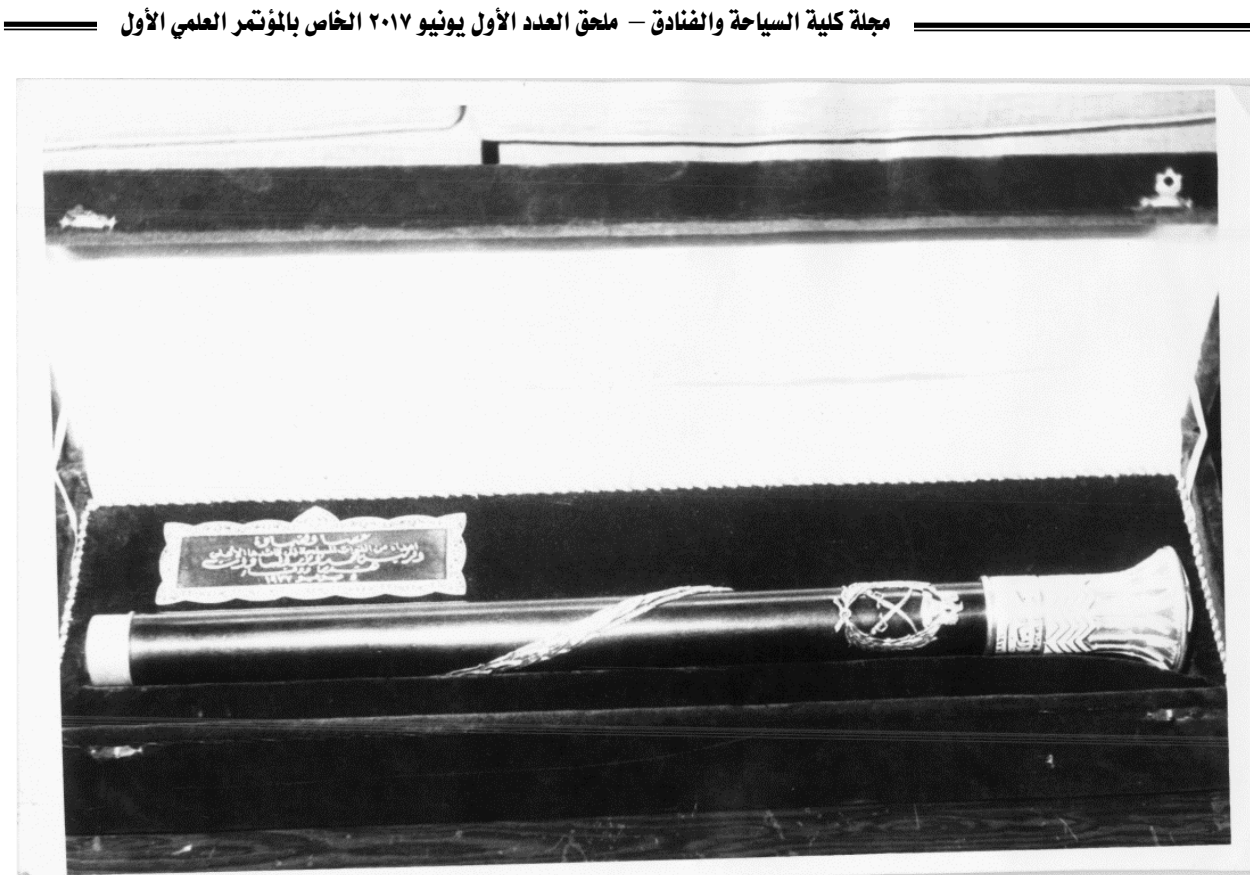

Plate no. l \&: the marshal's baton or the leadership baton of president Sadat in it box with the dedication.

After: Bibliotheca Alexandrian Archive

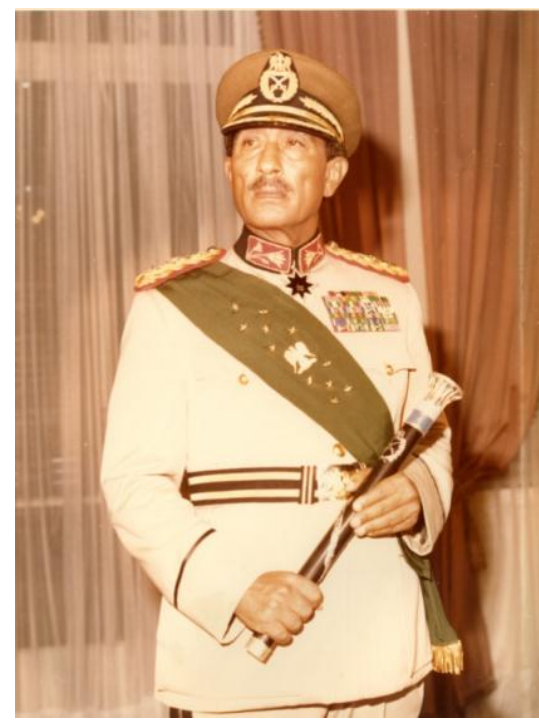

Plate no. 10: President Sadat with his full military uniform holding in his hand the marshal's baton, in a commemorative photo during the celebration of $7^{\text {th }}$ Oct. $19 \vee \mathrm{V}$. After: Bibliotheca Alexandrian Archive. 
Lecturer of Modern and contemporary history High Institute of Tourism of Abukir

${ }^{r}$ York Dictionary Of Military Terms, Librairie Du Liban Puplishers, $r \cdots$, libanon, p. 19

${ }^{r}$ Webester's Ninth New Collegiate Dictionary, Miriam-webster Inc., 191 ฯ, USA, p. ${ }^{\vee} \uparrow q$

'Gitana Zujiene, "The Gdl Marshals' Insignia And Their Place In Ceremonial Between The

Sixteenth And Eighteenth Centuries" in Lithuanian historical studies, vol. ' •, r... , p. rq

- York dictionary of Military terms, op. cit., p. 1 r 4

The Macquarie Dictionary, Macquaire library pty .Ltd.,Sydney, 199^,p. I r I

$\checkmark$ Spencer Tucker, A Global Chronology Of Conflict, vol. ', ABC-Clio, Santa Barabra, $r \cdot 1 \cdot, p \leqslant 07$

${ }^{\wedge}$ Gitana zujiene, op. cit., p.rq

${ }^{\natural}$ William Frederick Friedman, Six Lectures Concerning Cryptography and Cryptanalysis, Aegean Park Press, California, $199 \cdot$, pp. $r \cdot, r$ ।

1. Corinna Pike and Christopher Mccreery, Canadian Symbols of Authority, Dundurn, Toronto, r. Il, p. ov

"Hand-span according to the Arab measures equal 10. $\varepsilon \mathrm{cm}$.

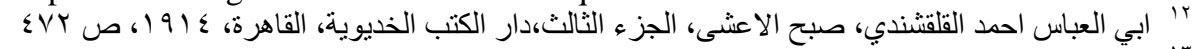

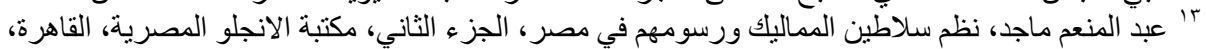

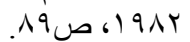

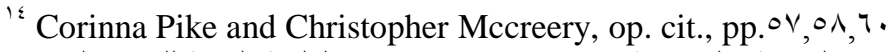

"1 رأفت عبدالرازق ابو العينين، الازياء الثرفية والعسكرية وزينتها في عصر الاسرة العلوية،النابغة للنشر والتوزيع،

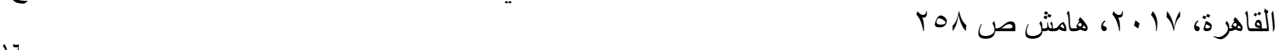

${ }^{17}$ The flag of Egypt during the sultanate from 1910 till $194 \mathrm{r}$ was a three crescent with pentagram star on a red background, so the crescent with the pentagram star was the symbol of Egypt in the time of Sultan Fuad ${ }^{\text {st }}$ till before $19 r \mathrm{r}$ when they changed the flag by the law no. $\leqslant \vee / 19 Y T$

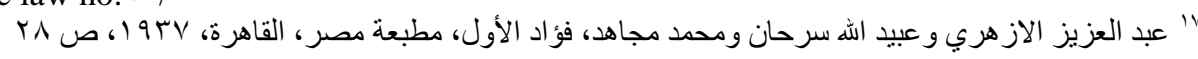

'^ The British hallmark Council, Hallmarks on Gold, silver and platinum, the assay office of great Britain, London, p. ${ }^{\prime 1}$

${ }^{19}$ Ibid., p. 11

r. Ibid, p.'r

"That was considered as nominal independence

$r \leqslant$ No. $r \leqslant \vee$, Royal Jewelry museum register.

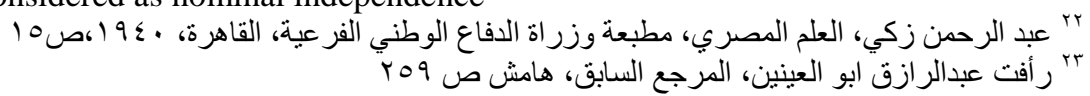

ro George Hart, The Routledge Dictionary of Egyptian Gods and Goddesses, Routledge, New York, $Y^{\prime} \cdot 0$, pp. $\vee \varepsilon, \vee 0$.

Carol Andrews, Amulets of ancient Egypt, British Museum press, London, $199 \varepsilon$, p. $\varepsilon$.

rV The flag of the Egypt was changed by the law no. $\leqslant \vee$ in $19 r r$, to be Crescent with three pentagram stars on a green back ground, so from this time the Crescent with the three pentagram stars represent the symbol of Egypt.

${ }^{\wedge}$ Barrie St. Clair McBride, Farouk if Egypt, Robert Hale, London, $197 \mathrm{~V}$, ,p. $7 \varepsilon$

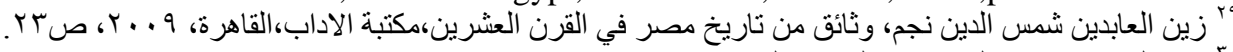

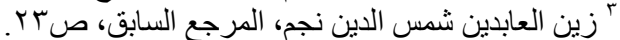

$$
\begin{aligned}
& \text { " مكتبة الملك فهد الوطنية، زيارة الملك عبد العزيز آل سعود التاريخية لمصر ، مكتبة الملك فهد الوطنية، الرياض، }
\end{aligned}
$$


${ }_{r r}$ Al-Mousawar, $11 / \cdot 1 / 19 \leq 7$, no. $111 \cdot$, pp. $1, Y$

${ }^{r}$ Al-Ahram, 1 $\varepsilon / \cdot 1 / 19 \leq \tau$, no. $r$ lNor, p. $r$;

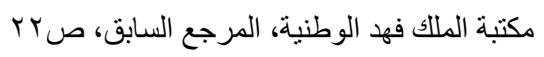

${ }^{r}$ No. $r \cdot \varepsilon$, the military museum register. Originally was in the royal Jewelry museum in Alexandria, no. $r \cdot \mathcal{l}$ in the museum register, but it was moved to the military museum at Saladin citadel in Cairo on ${ }^{\mathrm{rd}}$ October $19 \wedge \mathrm{v}$.

ro One of the earliest column types used in Egyptian temple like the granite column used in temples of king Unas of the fifth Dynasty and it was used during the Greco-Roman period too.

Richard Wilkinson, The Complete Temples of Ancient Egypt, Thames \& Hudson, New York,,$\cdots$, p. 7 T

${ }^{\top}$ That feature appeared in the Pharaonic New kingdom columns.

Richard Wilkinson, op. cit., p. TV

${ }^{r v}$ Both pictures from the archive of Bibliotheca Alexandrina and unfortunately, they are without any information or date.

Al-Ahram, $11 / \cdot r / 19 \leq \vee$, no. rr/Ar,p.l

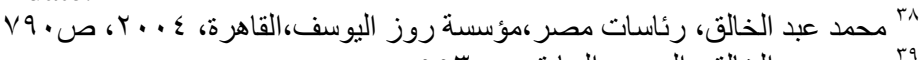

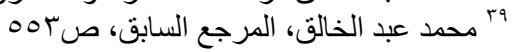

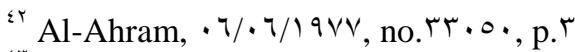

" محمد عبد الخالق، المرجع السابق، صبه

$\approx$ Sinai Star is a military Order created in $\vee \vee$ Feb. $19 \vee \varepsilon$ by law no. $9 /(9 \vee \varepsilon$. It has o awarded to any military person of the Egyptian armed forces that acts an extraordinary gallantry in direct combat with the enemy during the operations that indicate a rare valor, exceptional ability and dedication in redemption, which resulted in heavy losses to the enemy by thwarting his plans, defeating his forces, capturing his units, destroying his positions and equipment or seizing them either in land, sea or air.

سامح عبد الرحمن اللقاني، موسوعة القلائد والنياثنين والاوسمة والانواط و الميداليات المصرية، الاسكندرية،

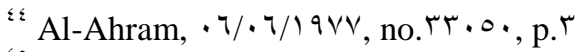

¿o Jehan Sadat, A Woman of Egypt, Simon \& Schuster, New york, 19^v, p. I

"Anthony McDermott, Egypt From Nasser to Mubarak :A Flawed Revoulation,vol. ${ }^{\longleftarrow}$, Routledge,London, $r \cdot 1 r, \mathrm{p} .{ }^{\circ} \mathrm{r}$

'I Ibid., p. ${ }^{\circ \mathrm{V}}$ 